\title{
Catching Up? Consolidating Liberal Democracy in Bulgaria and Romania after EU Accession
}

Citation for published version (APA):

Spendzharova, A., \& Vachudova, M. A. (2012). Catching Up? Consolidating Liberal Democracy in Bulgaria and Romania after EU Accession. West European Politics, 35(1), 39-58.

https://doi.org/10.1080/01402382.2012.631312

Document status and date:

Published: 01/01/2012

DOI:

10.1080/01402382.2012.631312

Document Version:

Publisher's PDF, also known as Version of record

Document license:

Taverne

Please check the document version of this publication:

- A submitted manuscript is the version of the article upon submission and before peer-review. There can be important differences between the submitted version and the official published version of record.

People interested in the research are advised to contact the author for the final version of the publication, or visit the DOI to the publisher's website.

- The final author version and the galley proof are versions of the publication after peer review.

- The final published version features the final layout of the paper including the volume, issue and page numbers.

Link to publication

\footnotetext{
General rights rights.

- You may freely distribute the URL identifying the publication in the public portal. please follow below link for the End User Agreement:

www.umlib.nl/taverne-license

Take down policy

If you believe that this document breaches copyright please contact us at:

repository@maastrichtuniversity.nl

providing details and we will investigate your claim.
}

Copyright and moral rights for the publications made accessible in the public portal are retained by the authors and/or other copyright owners and it is a condition of accessing publications that users recognise and abide by the legal requirements associated with these

- Users may download and print one copy of any publication from the public portal for the purpose of private study or research.

- You may not further distribute the material or use it for any profit-making activity or commercial gain

If the publication is distributed under the terms of Article $25 \mathrm{fa}$ of the Dutch Copyright Act, indicated by the "Taverne" license above, 
West European Politics

\section{Catching Up? Consolidating Liberal Democracy in Bulgaria and Romania after EU Accession}

\section{Aneta B. Spendzharova \& Milada Anna Vachudova}

To cite this article: Aneta B. Spendzharova \& Milada Anna Vachudova (2012) Catching Up? Consolidating Liberal Democracy in Bulgaria and Romania after EU Accession, West European Politics, 35:1, 39-58, DOI: 10.1080/01402382.2012.631312

To link to this article: https://doi.org/10.1080/01402382.2012.631312

曲 Published online: 09 Dec 2011.

Submit your article to this journal $\sqsubset$

Џll Article views: 5229

Q View related articles $\asymp$

4 Citing articles: 24 View citing articles 


\title{
Catching Up? Consolidating Liberal Democracy in Bulgaria and Romania after EU Accession
}

\author{
ANETA B. SPENDZHAROVA and MILADA ANNA VACHUDOVA
}

This article investigates the most important determinants of domestic institutional change in combating corruption and reforming the judiciary in Bulgaria and Romania since EU accession in 2007. It explores how EU and domestic incentives trigger domestic institutional change, and how the two interact with one another. It argues that political leaders and parties will only continue and deepen reforms in response to the twin forces of EU and domestic influence. The EU incentives that shape elite choices stem primarily from public monitoring by the European Commission of government performance and the possibility of sanctions by the EU. The domestic incentives centre on winning elections and holding power, with substantial variation explained in part by diverging sources of domestic support.

As the progress of liberal democracy ebbs and flows worldwide, there is widespread agreement that the post-communist states along the EU's old eastern border represent a success. Since the fall of communism in 1989, 10 states have passed through the EU's demanding pre-accession process. The tremendous benefits of EU membership created political incentives to satisfy the EU's extensive membership requirements. These incentives, along with certain characteristics of the pre-accession process that reward progress and publicise shortcomings, create the EU's leverage on domestic reform. EU leverage has helped compel candidates to reform the state and the economy, improving the quality of democracy and the efficiency of state institutions in various ways (Vachudova 2005; see also Sedelmeier 2011). By 2005, the eight post-communist states that joined the EU in 2004 were, on average, indistinguishable from the EU's old member states on measures of political rights and civil liberties (Cameron 2007: 199).

However, the two post-communist states that joined in 2007, Bulgaria and Romania, have struggled to achieve the same relative success. Severe 
problems with corruption, judicial quality and state capacity remain. During the pre-accession process, strict enforcement in some areas was limited to the adoption, not the implementation, of EU rules. In other areas, especially related to corruption, there were few specific rules to enforce. These problems have prompted the EU to implement a novel monitoring instrument, called the Cooperation and Verification Mechanism (CVM), in an attempt to trigger reform by extending EU leverage into the postaccession period. After 20 years of democratisation, Bulgaria and Romania find themselves in the category of 'semi-consolidated democracies' - in contrast to the other eight post-communist EU members that are considered 'consolidated' (Freedom House 2010).

Domestic conditions in Bulgaria and Romania at the moment of democratisation were less auspicious than in neighbouring states. A large literature on the comparative politics of post-communism has shown the importance of communist and even pre-communist legacies in shaping political trajectories after 1989. Bulgaria and Romania suffered under oppressive and highly clientelistic communist regimes that took power in societies with low levels of industrialisation and civil society organisation in the pre-communist period. The 'revolutions of 1989' in these countries were instead an internal communist coup where second-tier opportunists reinvented themselves as transitional democratic leaders, and then used the power of the state to win early elections. For much of the 1990s partial economic reform enriched the elite and entrenched networks of corruption while prolonging the economic hardships of the average citizen. In both countries the communist successor parties have been implicated in the most far-reaching and systematic corruption, as years of state capture by these parties would predict.

By 2000, however, both Bulgaria and Romania were making relatively dramatic progress. The benefits of qualifying for EU membership clearly inspired some of this effort, including significant domestic institutional reform (Grabbe 2006; Schimmelfennig and Sedelmeier 2004; Vachudova 2005; on limits see Epstein 2008; Haughton 2007). But was it enough? In this article we investigate whether and how domestic institutional change designed to strengthen the judiciary and stamp down corruption has continued in both countries since EU accession. These are important components of democratic consolidation that are at the core of the EU's concerns. Are Bulgaria and Romania catching up to the EU ECE 8 or are they sliding back? We observe little backsliding since accession (as do Levitz and Pop-Eleches 2010). But given the sad state of the judiciary and the presence of very extensive, high-level corruption at the moment of accession, the absence of backsliding is not the desired outcome - from the point of view of democratic consolidation or indeed of the EU. So are they catching up? The record here is mixed. Our dependent variable is domestic institutional change to create an effective judiciary and to fight corruption. We observe substantial variation between successive governments in each country and between the two countries over time. 
What explains this variation? We hypothesise that political leaders and parties will only continue and deepen reforms in response to the twin forces of EU and domestic influence. The EU incentives that shape elite choices stem primarily from the public evaluations of government performance by the Commission in the twice-yearly CVM reports, and the possibility of putative actions by the EU, chiefly related to EU funding and Schengen entry. These have been similar in the two cases. The domestic incentives for political leaders are primarily electoral ones, chiefly the salience of judicial and corruption-related reforms for the voters; the positions of other parties, especially potential coalition partners; and the role of civic groups in publicising government performance and galvanising public pressure.

In contrast to EU incentives, we show that domestic incentives have differed between the two cases and over time. In Bulgaria a new party used a strong anti-corruption platform to establish itself in the party system and win the 2009 election. The EU's CVM mechanism and the freezing of some EU funds in 2008 had helped highlight the problem of corruption for the electorate, making this platform even more attractive - and making the actual implementation of reforms by the new government more necessary. In Romania a new president also came to power on a strong anti-corruption platform, but this was back in 2004. At that time, the EU's strong preaccession leverage helped create a substantial momentum for reform. But this petered out after accession thanks to collusion among much of the political elite, which closed ranks in order to roll back reform. Neither sharp EU criticism, frozen EU funds, nor domestic groups highlighted the problem of corruption for the electorate, which was anyhow preoccupied by Romania's more severe economic problems. In 2010 and 2011, however, mounting pressure from the Commission and the threat of delayed Schengen entry rekindled some reform in Romania.

The rest of this article is organised in four parts. The first part shows how Bulgaria and Romania have performed in four areas of domestic institutional change in comparison to their neighbours. The second part sets out our theory that the interplay of EU and domestic incentives determines the outcome and speed of domestic institutional change in combating corruption and reforming the judiciary. The third part traces how this has played out in Bulgaria, and the fourth part in Romania.

\section{Catching Up or Sliding Back?}

In this section we present data that illustrates how domestic institutional reform in Bulgaria and Romania compares to reform in the eight postcommunist EU members that joined the EU in 2004 (called here the EU ECE 8). As illustrated in Figures 1 and 2, Bulgaria and Romania are clearly laggards in government effectiveness and regulatory quality, though they have improved substantially over time. In judicial reform and the fight against corruption depicted in Figures 3 and 4 they have, on average, 


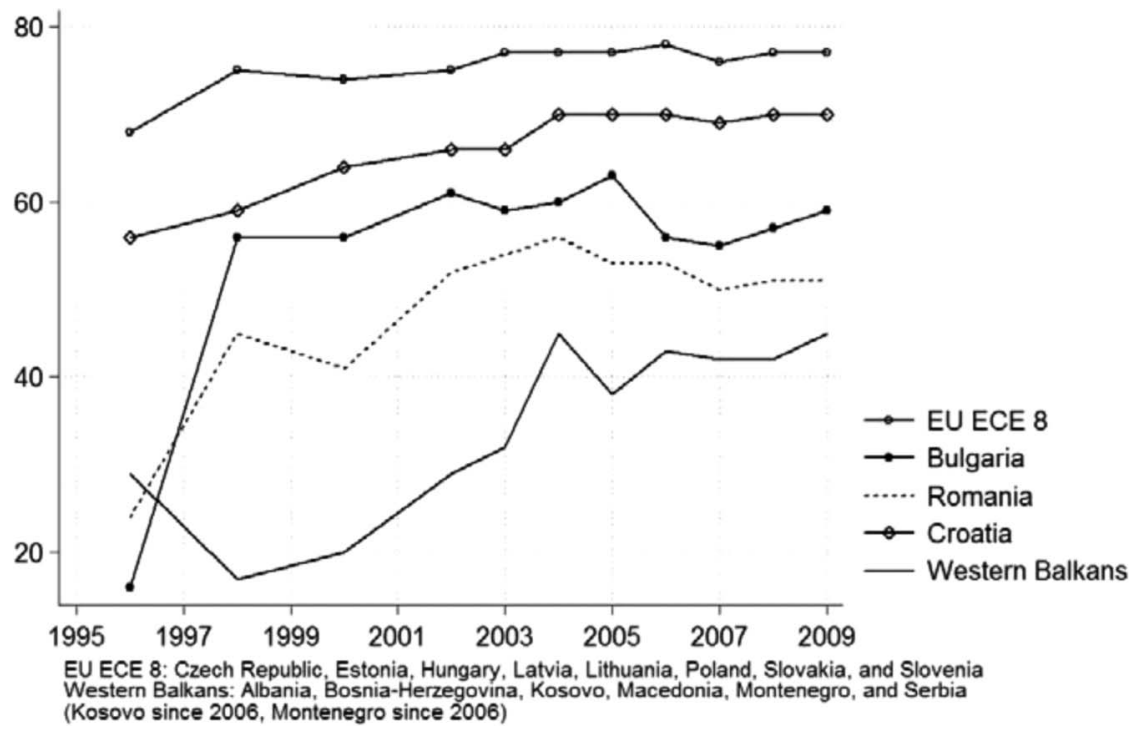

Note: This index combines responses on the quality of public service provision, the quality of the bureaucracy, the competence of civil servants, the independence of the civil service, and the credibility of the government's commitment to policies. It focuses on 'inputs' required for the government to produce and implement policies well and deliver public goods. In this graph, the overall percentile rank of the countries or country groups are shown, with higher numbers indicating better performance.

Sources: World Government Indicators (WGI) 1996-2009, World Bank, available at http:// info.worldbank.org/governance/wgi/index.asp (accessed 7 January 2011); Kaufmann et al. (2010).

performed even worse as compared to the EU ECE 8. However, they have performed significantly better than the Western Balkan states that are still in the membership queue, with the exception of Croatia. The data here and in other studies is consistent with the argument that the process of joining the EU did help move Bulgaria and Romania away from the administrative and economic backwardness characteristic of the Balkan region.

One of the key scope conditions for explaining the quality of institutional change discussed in the introduction to this special issue is state capacity (Börzel and Risse 2012). However, Figures 1 and 2 show that state capacity in Bulgaria and Romania does not differ significantly. Thus, state capacity defined as government effectiveness and regulatory quality - cannot explain the variation in Bulgaria and Romania's performance in curbing corruption and improving judicial quality. Both Bulgaria and Romania experience power asymmetry vis-à-vis the EU, where the two countries have much to gain from sustained compliance with EU demands. However, there is no variation in the asymmetry and neither country possesses resources that 
FIGURE 2

REGULATORY QUALITY (PERCENTILE RANKS)

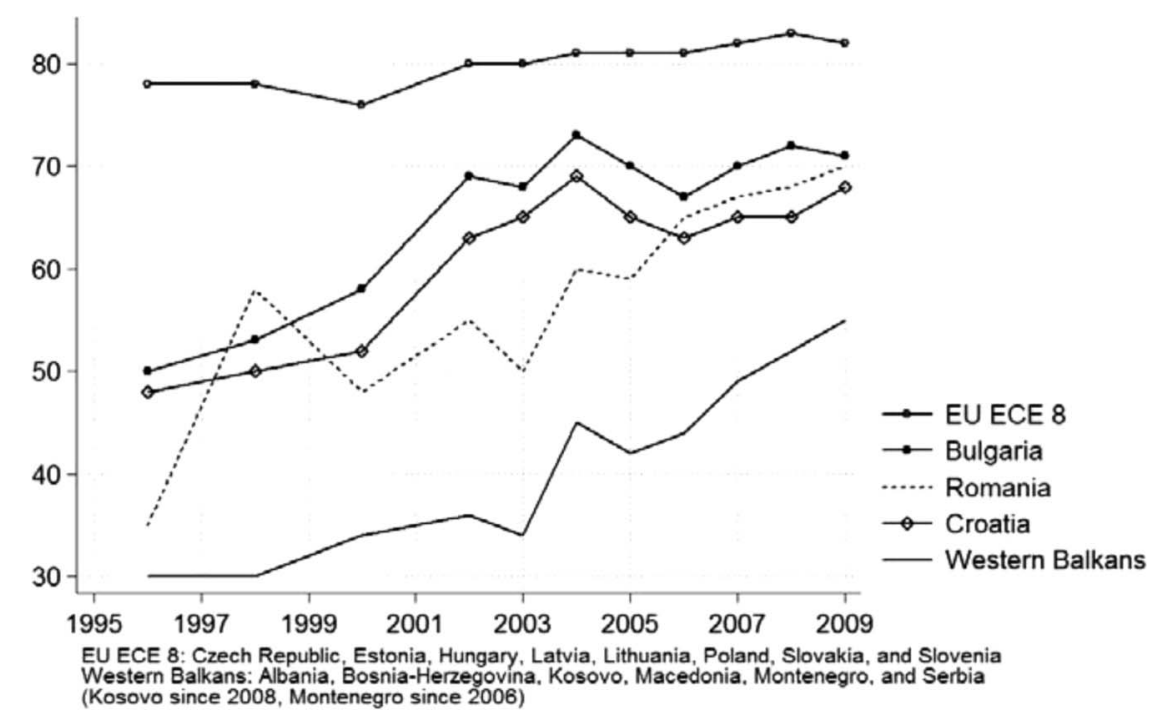

Note: This index gauges the incidence of market-unfriendly policies such as price controls or inadequate bank supervision, as well as perceptions of the burdens imposed by excessive regulation in areas such as foreign trade and business development. In this graph, the overall percentile rank of the countries or country groups are shown, with higher numbers indicating better performance.

Sources: World Government Indicators (WGI) 1996-2009, World Bank, available at http:// info.worldbank.org/governance/wgi/index.asp (accessed 7 January 2011); Kaufmann et al. (2010).

would allow it to resist EU pressure. Thus this scope condition cannot account for the diverging outcomes in our analysis either. Instead, we argue in the next section that, among the potential scope conditions discussed in this special issue, domestic politics plays the most significant role in determining whether Europeanisation pressures will result in lasting domestic institutional change.

The composite measure of government effectiveness from the World Bank in Figure 1 shows the gap between the eight post-communist countries that would join the EU in 2004 (the EU ECE 8) and Romania and Bulgaria in 1996 when the data set was started. Bulgaria performs slightly better than Romania overall, but deteriorates significantly during the term of the Bulgarian Socialist Party (BSP)-led government; it then rebounds. Figure 2 shows that all post-communist EU candidates have made quite consistent progress in market liberalisation over the past 15 years. The lion's share of the EU acquis still relates to the functioning of the internal market: Removing the state from the economy through deregulation, privatisation, and lowering state subsidies has gone hand in hand with improving how state institutions oversee and regulate economic activity. Thus the steady 


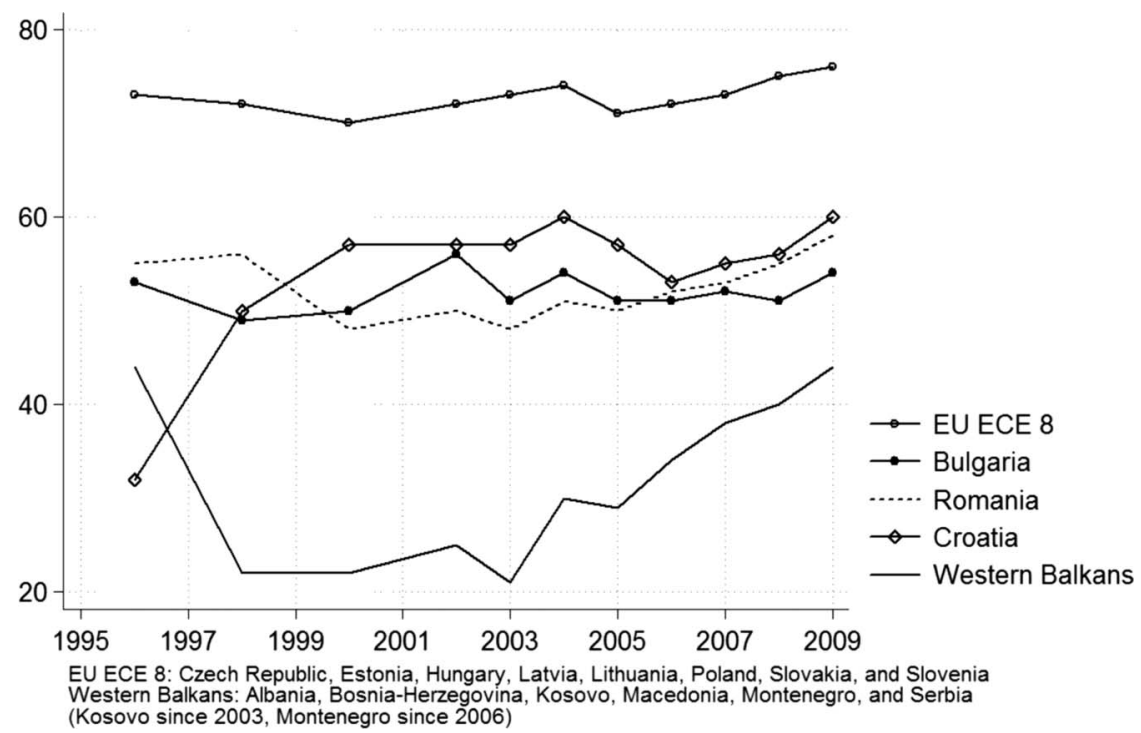

Note: This index measures whether agents have confidence in and abide by the rules of society. It includes perceptions of the incidence of crime, the effectiveness and predictability of the judiciary, and the enforceability of contracts. In this graph, the overall percentile rank of the countries or country groups are shown, with higher numbers indicating better performance. Sources: World Government Indicators (WGI) 1996-2009, World Bank, available at http:// info.worldbank.org/governance/wgi/index.asp (accessed 7 January 2011); Kaufmann et al. (2010).

progress exhibited by Romania, Bulgaria, and also Croatia in Figure 2 suggests that the EU has had the most influence in this area, progressively narrowing the gap with the EU ECE 8. Overall, this dovetails with other studies which have shown that post-communist states, as a group, have not reversed course after accession and are quite good at implementing the acquis (Sedelmeier 2012; see also Sedelmeier 2008; Levitz and Pop-Eleches 2009).

Figures 3 and 4 present the regional trends in domestic institutional change aimed at reforming the judiciary and controlling corruption. The composite measure of the rule of law paints a much less positive picture of the ability of EU leverage to transform domestic institutions - both before accession and after it. The gap between Romania and Bulgaria, on the one hand, and the EU ECE 8, on the other, is large and has decreased only a little in 12 years. On this measure Croatia is also lagging well behind the EU ECE 8. This is not surprising since the indicators that make up this composite measure include the effectiveness of the judiciary - an institution that was only indirectly subject to EU leverage and has been notoriously difficult to reform. This composite measure also reflects perceptions about the criminality of economic and political activity, which we would expect to 


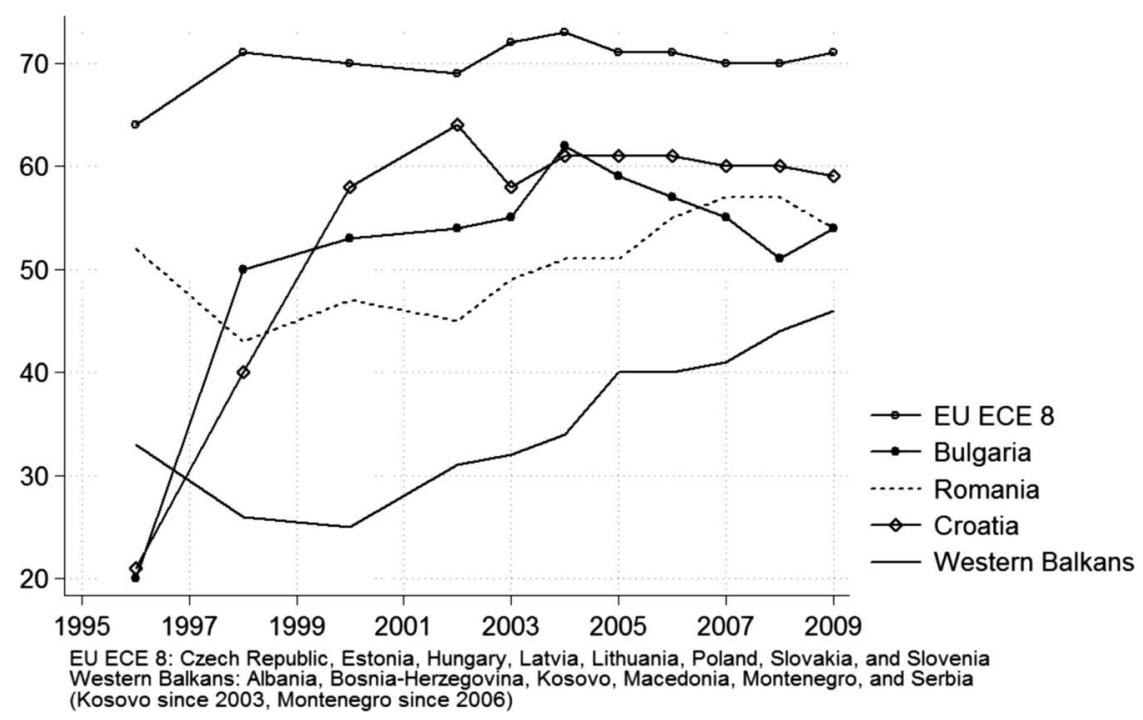

Note: This index measures perceptions of corruption, conventionally defined as the exercise of public power for private gain. The survey includes the frequency of additional payments to get things done, the effects of corruption on the business environment, grand corruption in the political arena, and state capture by groups of elites. In this graph, the overall percentile rank of the countries or country groups are shown, with higher numbers indicating better performance. Sources: On the validity of corruption data, see Treisman (2007). World Government Indicators (WGI) 1996-2009, World Bank, available at http://info.worldbank.org/governance/wgi/index.asp (accessed 7 January 2011); Kaufmann et al. (2010).

be much higher in a country with high perceptions of corruption and years of partial economic reform. The figure is consistent with the argument that substantial improvements in the rule of law require a sustained domestic commitment to institutional change (Spendzharova 2008). Helping to create this kind of commitment is one of the purposes of the EU's CVM, discussed below.

The corruption measure is similar to the rule of law measure, although it shows greater improvement over the last 15 years from a lower starting point, especially in Bulgaria and Croatia. While more absolute progress appears to have been made in the area of corruption, the gap between Bulgaria, Romania, and the EU ECE 8 is still considerable (for additional data that shows similar results, see Vachudova 2009). Around the time of EU accession, this measure shows the deterioration of corruption control measures under Bulgaria's BSP-led government but improvement in such measures in Romania. However, the last data point, our qualitative analysis, and the EU's most recent CVM reports suggest that the trends have now reversed. 


\section{Consolidating Liberal Democracy after EU Accession: Fighting Corruption and Reforming the Judiciary}

Over the last two decades, two factors have intermittently been successful in prompting Bulgaria's and Romania's governments to pursue domestic institutional change in reforming the judiciary and controlling corruption: EU leverage and domestic incentives (Ristei 2010). As illustrated in Figure 5, we conceptualise domestic incentives as a mediating variable that can reinforce EU leverage and boost reform when the two variables are aligned. But if domestic incentives run counter to the EU ones, our model predicts stagnation or even backsliding. In the latter scenario, we expect rhetorical compliance, but domestic institutional reforms will largely be crafted to benefit the governing elites: corruption will not be curbed and judicial quality will not improve. In other words, EU incentives are powerful when they are mirrored by domestic incentives related to winning elections and holding power. Börzel and Pamuk's (2012) article in this issue highlights the same dynamics in the Southern Caucasus. For example, a positive EU report will be worth more to a government that considers EU approbation as essential to maintaining its popular support. EU conditionality will be more effective in motivating governments if the EU is threatening to withhold something that voters really want, such as entry into Schengen.

Our argument is embedded in the rational choice institutionalism literature that examines changing opportunity structures for domestic actors (Keohane 1984). So far, the related EU enlargement literature has focused on domestic actors and institutions that can block adaptation to EU requirements, and on domestic reform coalitions that have mobilised around EU opportunity structures (Börzel and Risse 2012). To refine this analysis, we draw a distinction between the opportunity structures and incentives promoted by the EU and those existing on the ground. This distinction allows us to understand better why European rules, policies, and practices do not 'travel' easily even when external adaptational pressure is high.

From the range of mechanisms at the disposal of international actors discussed in the introduction to this issue (Börzel and Risse 2012), we focus on the EU's use of positive and negative incentives. We measure EU

FIGURE 5

CAUSAL DIAGRAM

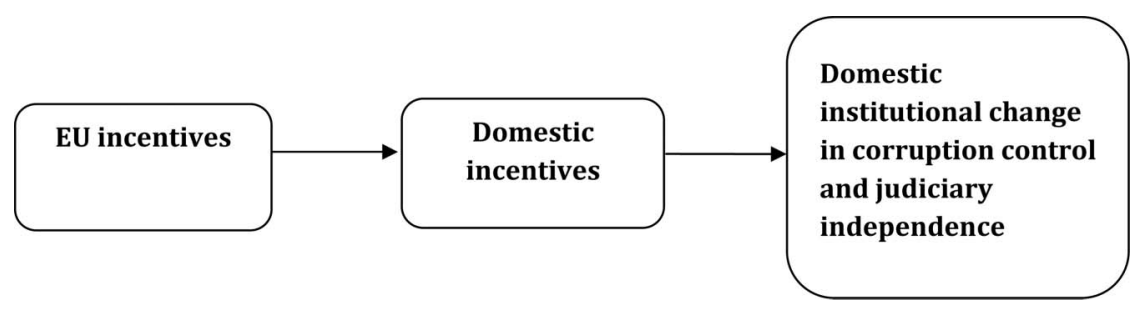


incentives using the CVM launched by the Commission in December 2006. The purpose of the CVM is 'to smooth the entry of both countries and at the same time to safeguard the workings of its [the EU's] policies and institutions'. The Commission created 'benchmarks' for assessing progress in judicial reform, corruption, and organised crime, and set up teams to monitor domestic institutional change in these areas. So far seven progress reports have been published for each country (the main reports in June/ July and the interim reports in February of each year). ${ }^{1}$ While the EU's previous reports on the progress of candidate states were often criticised as being too vague, these CVM reports are remarkably detailed, following the activities of relevant institutions and tracking the outcome of high-level criminal cases. Hinting at the likely longevity of the CVM mechanism, the Council declared in 2010 that it is an 'appropriate tool' that will stay in place 'pending the results expected in this framework' (Council of the European Union 2010: 4).

We argue that since accession the causal importance of domestic incentives has increased substantially (see also Noutcheva and Bechev 2008). Why? In a variety of ways, EU leverage helped empower domestic coalitions with liberal democratic aims and undermine illiberal ones (Vachudova 2005). On the eve of EU membership negotiations, almost all political parties adopted an EU-compatible agenda; subsequently, all ruling political parties helped bring the negotiations to a close (Vachudova 2008). Now that membership has been achieved, however, the obvious externallyimposed costs of not pursing reforms or complying with EU rules have diminished. When the preferences of powerful partisan veto players run against the reforms adopted before accession, those institutional changes risk turning into empty shells, and even being reversed (Dimitrova 2010; Sedelmeier 2012). The CVM aims to prolong some of the EU's leverage after accession in the critical areas of judicial quality, the fight against corruption, and also organised crime - areas where powerful domestic players in Bulgaria and Romania have openly tried to scuttle institutional reform.

Domestic incentives to fight corruption are generally tied to getting elected or re-elected (see also Börzel and Pamuk 2012). Political parties may choose to build their electoral platforms on improving the rule of law. Once these commitments have been made, the credibility of the political party may hinge upon its capacity to deliver. The chances for re-election may plummet if voters no longer trust that the party will implement domestic institutional reforms to fight corruption and organised crime. Here, the resources of society to hold political leaders accountable for the reforms they have (or have not) promised are critical (see also Noutcheva and Düzgit 2012). A free media and an active civil society are essential to analyse the performance of the governing political parties and highlight shortcomings (Primatarova 2010). Still, the core mechanism in our argument is an electoral one. 


\section{Bulgaria}

Since Bulgaria joined the EU in 2007, it has been ruled by two different governments: the coalition government led by the BSP from 2005 to 2009, and the GERB (Citizens for European Development of Bulgaria) government since 2009. These two governments have differed substantially in their approach to corruption and the rule of law because they have different sources of domestic power: the BSP's has been built on clientelism and state capture and the GERB's on a popular backlash against corruption.

To promote domestic institutional reform in Bulgaria after accession, the EU has used both positive incentives, such as funding and expert advice, and negative incentives, such as freezing EU funds and imposing fines. The June 2007 CVM report detailed the most serious shortcomings: judicial reform, corruption, and organised crime (European Commission 2007). A year later, the June 2008 CVM report established that despite some formal domestic institutional changes such as anti-corruption legislation and action plans, practical results were missing, especially in the realm of managing EU funds (European Commission 2008).

The context of EU incentives in Bulgaria changed substantially in 2008 after the EU froze a number of funding programmes due to mismanagement, and demanded that Bulgaria improve 'transparency and the regulation of financial asset flows and transactions' (European Commission 2008: 5). This marked a dramatic shift to using negative incentives to induce change. In response, the BSP-led coalition complied with some of the requested institutional and legal changes, but concrete results and genuine reform were largely missing (European Commission 2009). The domestic incentives for the BSP-led government were geared toward rent-seeking, especially in the realm of public procurement and managing EU funds.

A 2008 Transparency International survey suggested that Bulgaria had the highest level of corruption in the EU. It attributed the entrenchment of corruption to a lack of transparency in the public procurement deals of the coalition government, and political pressure on the judicial system (Sega Newspaper, 23 September 2008). The Center for the Study of Democracy (CSD 2007) concurred that even though low-level administrative corruption was in decline, 'political corruption involving members of the government, MPs, senior state officials, mayors and municipal councilors' was on the rise. EU accession did help curb administrative corruption, income concealment, tax evasion, and informal employment. However, deeper domestic institutional changes were needed to close loopholes and increase transparency in the management of state assets and public procurement (CSD 2007: 6).

The public procurement market highlights the gaps in the domestic institutional framework that allowed clientelism to flourish. By 2008, this market, measured by concluded contracts, had doubled in both number and value. At the same time, the share of the companies that participated in 
public procurement tenders dropped significantly, and the 25 largest contracting authorities commanded more than 45 per cent of the total value (CSD 2009: 82). The lack of legal and institutional provisions for fair competition created a fertile environment to establish clientelistic relations and demand kickbacks in exchange for large government contracts. This was especially true in the biggest public procurement markets such as pharmaceuticals, fuels, business services, office equipment, and motor vehicles (CSD 2009: 82).

The Bulgarian case also shows how NGOs can also become a tool of corruption and rent-seeking. As democracy promotion aid for Bulgaria was phased out, EU and other grants distributed by the government constituted 40 per cent of NGO funding. The CSD (2009: 38) chronicled a worrying trend of 'civil society capture' by elites in order to benefit from EU funding. By 2009, the number of Bulgarian NGOs had increased five-fold. The CSD found that 75 per cent of Bulgarian MPs and ministers and 90 per cent of Bulgarian municipal mayors were members of NGO boards. Public officials developed 'loops of NGOs' which obtained generous grants from the state despite flagrant conflicts of interest (CSD 2009: 40). Members of parliament often lobbied their colleagues to award EU projects to the NGOs where they sat on the board. The Ministry of Regional Development frequently cherrypicked winners of EU-funded regional development and rural aid projects. Civil servants in charge of project management offered to process smoothly project reports and receipts against 15 per cent of the project value (Deutsche Welle, 1 August 2008).

In sum, while we observe superficial domestic institutional changes addressing the EU's recommendations to combat corruption and improve the rule of law, Bulgaria's BSP-led coalition government did not deliver convincing results. In fact, high-ranking politicians were involved in clientelistic networks and Bulgaria lost ground in the fight against corruption. This is consistent with our theoretical expectations that the absence of strong domestic incentives to promulgate deeper domestic institutional change will lead, at best, to partial progress in democratic consolidation. Let us now examine how domestic incentives changed for the new GERB party following the 2009 parliamentary elections.

GERB's entry on to Bulgaria's political scene highlights the importance of domestic electoral incentives. Political developments in Bulgaria since 1989 suggest that clientelism and corruption undermine economic stability and lead to electoral failure. An earlier BSP government that had also vigorously pursued rent-seeking ultimately faced an escalating economic crisis, country-wide protests, and ousting in early elections. (Ganev 2007; Spendzharova 2008; Vachudova 2009). In 2009, the widespread mismanagement and freezing of EU funds contributed to the electoral failure of the BSP-led coalition government. It also made the anti-corruption agenda of the opposition all the more popular and, from the point of view of the citizen and some domestic groups, urgent. A new centre-right political party, 
GERB, seized the opportunity and won the parliamentary elections on a strong anti-corruption platform. Its leader, Boyko Borissov, became prime minister. Both the European Commission in its July 2010 CVM report and Bulgarian think tanks such as the CSD pointed out a clear shift in the political will of the Bulgarian government to tackle corruption when the GERB cabinet took office (CSD 2010; European Commission 2010a).

We have seen that EU incentives alone did not have sufficient traction on the BSP government. For the GERB government, the domestic incentives for reform have been much stronger: it ran an election campaign focused on curbing corruption and limiting the influence of organised crime. Borissov emphatically pledged that prosecuting corruption and abuse of EU funds would be a core priority of his government (Sofia Echo, 6 July 2010). By contrast, the policy agenda of the preceding BSP-led government focused on job creation and economic growth (Cholova 2010). GERB's choice of policy priorities during the 2009 election campaign resonated well with public opinion. Voters clearly placed fighting corruption as a top priority: while 35.6 per cent of respondents agreed that anti-corruption should be a top government priority in 2004, 64.7 per cent supported that statement in 2008. Similarly, business managers' tolerance of corruption and their inclination to engage in corruption were at an all-time low in 2009 (CSD 2009: 25).

In line with the domestic empowerment mechanism, EU incentives have provided a strong impetus to boost judicial reform and curb corruption (Vachudova 2005). Following the release of the July 2010 CVM report, the government enacted substantial domestic institutional changes to address EU and domestic criticism. Bulgaria's Ministry of Justice initiated a legal ban on the participation of high-level public officials in NGO management boards. The government streamlined the public tenders procedure and made it more transparent. A new Law on the Prevention and Detection of Conflicts of Interests from 2009 obliged public officials to declare and avoid conflicts of interest (CSD 2009: 40).

In addition to domestic institutional changes, the Borissov government showed more consistent behavioural compliance with EU pressure for highlevel prosecutions. Three magistrates were dismissed from office and 15 others received disciplinary sanctions (European Commission 2010a: 5). Businessman Mario Nikolov was sentenced in May 2010 to 12 years in prison on charges of fraud and embezzling $€ 7.5 \mathrm{~m}$ of EU funding. Nikolov was also convicted of money-laundering in a related case, both of which came to court following an investigation by OLAF, the EU's anti-fraud office (Trauner 2009; The Financial Times, 20 July 2010). As a result, the first CVM report assessing the GERB government recognised that 'organised crime [was] actively tackled for the first time since the inception of the CVM' (European Commission 2010a: 3). The Commission's decision to unfreeze blocked EU funds after a positive CVM report in July 2010 was a major success for the GERB government (The Financial Times, 20 July 2010). The February 2011 interim report, albeit positive in outlook, recommended 
further domestic institutional changes such as establishing an independent authority to identify and sanction conflicts of interest, and to confiscate unexplained accumulations of wealth (European Commission 2011).

Reforming the judicial system, however, remains Bulgaria's toughest challenge. Even though the government created a special court to speed up prosecution of cases related to organised crime, dealing with the cases impartially and efficiently remains problematic (European Commission 2011: 5). Magistrates have very little time to spend on each case. Lawenforcement agents do not have adequate resources or authorisation to conduct the investigations and secure quality evidence that can lead to successful indictments in court (Capital Newspaper, 17 July 2009). Most important, in both Bulgaria and Romania, stonewalling by 'conservatives' from within the highest ranks of the judiciary itself has blocked comprehensive institutional reform and propagated corruption (SAR 2011).

Established NGOs in Bulgaria such as the Centre for Liberal Strategies and the CSD have been pivotal in exposing corruption and creating pressure for transparency and accountability in government. Several similar NGOs exist in Romania, including the Romanian Academic Society (SAR) and Pro Democracy. However, since officials from ruling parties now disburse substantial amounts of NGO funding, smaller and less-established NGOs are likely to refrain from criticising the government - a serious blow for accountability, transparency, and domestic pressure for reform in both Bulgaria and Romania (SAR 2011).

\section{Romania}

In Romania, political will to tackle domestic institutional reform has been uneven since 2007. There was a surge in activity in the run-up to accession, but much of the political elite responded by closing ranks and working to dilute or remove the curbs on corruption that were implemented at that time. Unlike in Bulgaria, where a new party exploited the failure of the government to fight corruption, in Romania some of the old parties worked to push the issue under the rug. Nevertheless, when the EU has put strong pressure on Romania, the government has responded, mainly by passing legislation in the parliament. President Traian Basescu, in office since 2004, built his reputation on the fight against corruption. Pressured by criticism from the Commission, his party again pushed through some reform in 2010, most importantly the resuscitation of Romania's anti-corruption agency. As Mihaiela Ristei argues, even in Romania there has been progress in the fight against corruption when EU leverage and electoral pressure have created political incentives for some domestic elites to spearhead reforms (Ristei 2010).

For the last two decades, Romanian domestic politics have experienced high-level political drama surrounding the issue of corruption. The former communist party, led by Ion Iliescu, ruled from 1989 until 1996 under several names, ending its rule as the Party of Social Democracy in Romania 
(PDSR). In 1996 it was defeated by a broad coalition of parties led by the Democratic Convention of Romania (CDR). This government changed the trajectory of Romania, orienting it squarely toward fulfilling the requirements of EU membership, including tolerance for Romania's Hungarian minority and rapid economic liberalisation. The CDR lost the 2000 elections due mainly to the economic hardships of structural economic reform and infighting within the coalition. The former communist party, now called the Social Democratic Party (PSD), won these elections and Iliescu became president once again (on these permutations, see Pop-Eleches 2008). The PSD government continued Romania's preparations for EU membership, but like the BSP-led government in Bulgaria it was mired in accusations of corruption that contributed to its defeat in 2004. Traian Basescu from the Liberal Democrat Party (PDL) won the presidency in 2004 on a vehement anti-corruption platform. A coalition government was formed of several parties under the leadership of Prime Minister Calin Popescu-Tariceanu of the National Liberal Party (PNL). Before long, the PSD and the PNL were working together to block Basescu's reforms, evidence of the lack of broadbased support for reform among Romania's political parties that has troubled the EU (Trauner 2009; see also Buniewicz et al. 2009).

As 2007 approached and the Commission considered whether to activate the one-year postponement of Romania's EU accession, it exerted substantial pressure on the Romanian government (Ristei 2010: 23). Basescu appointed and supported government officials in 2005 that were very energetic in the fight against high-level corruption. But Basescu's opponents in the PSD and the PNL charged that their investigations were politically motivated, targeting politicians from opposing political parties. The most active was Minister of Justice Monica Macovei, whose work to improve the judiciary and bring cases to trial was heralded in European capitals as a great breakthrough. Romania's initial CVM reports were consequently much more positive than Bulgaria's. Many politicians in Romania, however, disagreed and the parliament voted overwhelmingly 322 to 108 to impeach Basescu in April 2007 for infringing the rights of the government, the parliament, and the judiciary. This impeachment had to be put to a referendum: 74 per cent voted against removing Basescu (turnout was only 44 per cent: The Financial Times, 21 May 2007). Nevertheless, Macovei was sacked by the PNL prime minister in 2007, and this met with little protest in Bucharest (The Financial Times, 27 March 2007, 12 June 2007).

By 2008 it was clear that the reform momentum following Basescu's presidential victory in 2004 had been stopped and even reversed. The Romanian parliament continued its habit of using its veto to prevent highprofile cases against politicians from going to court. And Romania's judges routinely gave only the mildest sentences for those that did. For example, of the 109 cases that were prosecuted in 2007 by Romania's anti-corruption agency, headed by Macovei appointee Daniel Moran, only 25 resulted in prison sentences, mostly for the minimum of three years (The Economist, 
31 July 2008). ${ }^{2}$ Reform of the judiciary and battling corruption played almost no role in the campaign in the run-up to the December 2008 elections. The Romanian economy, crippled by the global financial crisis, was the main concern; citizens focused on unemployment, the economy, and inflation (European Commission 2010b). After the elections Basescu's party, the PDL, went into coalition with the PSD, making new reforms very unlikely. This coalition, led by Emil Boc (PDL), fell apart in October 2009, paving the way for a new PDL government led by Boc in coalition with the Hungarian and minority parties. This new, more auspicious coalition government took office in December 2009. However, Romania was hit much harder by the 2008 economic crisis than Bulgaria. The government had to implement a difficult austerity package to respond to the economic crisis; for this it was viciously attacked by the opposition and lost substantial popular support.

What the EU had applauded most enthusiastically was an important domestic institutional change: the creation in 2007 of the National Integrity Agency (ANI) that had substantial powers to force public servants to disclose their assets, to investigate individuals who could not adequately explain where their assets came from, and to seize unexplained assets. It also required public officials to submit conflict-of-interest declarations. The largest number of cases against high-level politicians pursued by this agency involved politicians from the PSD. In April 2010 many of the ANI's activities were declared unconstitutional by the Constitutional Court after having also been attacked in parliament. Press reports revealed that seven of the nine judges on the Court were themselves being investigated by the ANI. President Basescu promised in Brussels that Romania would reach its objective of 'controlling the income of those in power and investigating the origin of their wealth' even though the ANI had been in practice 'annihilated' by the Constitutional Court (EurActiv, 23 April 2010; see also Dix 2010).

The July 2010 CVM report of the European Commission was highly critical, especially of the destruction of the ANI, and declared that Romania was in breach of its accession commitments. The Commission called on Bucharest to 're-establish the ANI's powers to propose the effective forfeiture of unjustified wealth' (European Commission 2010a: 7). The Commission also observed that Romania lacks 'broad-based political support in favour of transparency and the effective protection against corruption and conflict of interest' (European Commission 2010a, 7). Soon after, in August 2010, both houses of the Romanian parliament voted to resurrect the ANI; this was widely understood as a direct result of EU pressure. The PSD, however, boycotted the vote (Eur Activ, 17 August 2010). In the February 2011 interim CVM report the Commission regretted that important high-level corruption cases had seen little movement in court since the last assessment (European Commission 2011). The performance of government officials in many areas remains poor since accountability is largely absent and political allegiance is the main determinant of success (SAR 2011). 
There has been some institutional change aimed at improving the capacity and the consistency of the judiciary. New criminal and civil procedure codes were passed in 2010, though an overall assessment of the performance of the judiciary is still missing (European Commission 2010a). Some reformers have joined the Supreme Council of the Magistracy, whose duties include appointing and disciplining judges (Geissler and Rebegea 2011). Two Senate-appointed seats were created for representatives of civil society. In June 2011 it seemed evident that the Senate and the Constitutional Court were endeavouring to fill these seats with individuals close to the PSD, such as the wife of a PSD deputy (Nineoclock.com, 14 June 2011; Hotnews.ro, 10 June 2011).

In late 2010 the question of Bulgaria and Romania's entry into the Schengen free movement area took centre stage. Press reports had speculated that Romania would have to produce a functioning ANI to gain admission to Schengen. ${ }^{3}$ Formally, the Commission has repeatedly stated that there is no connection between the technical requirements for Schengen entry and the CVM benchmarks. However, in December 2010 France and Germany publicly linked the two, declaring in a joint letter that Schengen entry should be postponed until 'both member states have initiated clear and objective, sustainable and irreversible positive developments in the fight against corruption and organised crime and in reforming the judicial system' (The Financial Times, 21 December 2010). ${ }^{4}$ In June 2011 the member states further delayed a decision on Schengen entry for both countries.

Since Schengen entry is strongly desired by Bulgarian and Romanian voters, using Schengen as a reward for meeting CVM benchmarks should significantly increase the external incentives for ruling parties to deliver reform. Reflecting differences in domestic incentives, however, the two governments have responded quite differently. The Borissov government immediately agreed that significant work needed to be done, and promised to redouble its efforts. Given how closely Borissov has wedded his agenda with that of the EU, at least rhetorically, this strategy makes sense - especially in the context of the abiding respect of Bulgarian citizens for the EU. The Boc government, in contrast, took umbrage and accused Paris and Berlin of discriminatory action seeking a 'two-speed Europe'. Romanian Foreign Minister Teodor Bachonschi declared that Romania may withdraw from the CVM (Sofia News Agency, 22 December 2010; EurActiv, 4 January 2011). The Commission, for its part, reminded Romania that it can only phase out the CVM once the benchmarks are fulfilled (EurActiv, 4 January 2011). Basescu and the Boc government appeared to be mobilising domestic opinion against the EU, perhaps because they cannot deliver far-reaching reform.

But Basescu continues to propose institutional changes that seem helpful to strengthening the judiciary and fighting corruption. In a package of constitutional reforms that was well received in Brussels in June 2011, Basescu proposed, for example, limiting parliamentary immunity. In an advisory opinion this was rejected as unconstitutional by the Constitutional 
Court that is controlled by the PSD. It would be wrong to consider Basescu's party, the PDL, as outside of the political cartel that benefits from institutional stasis and corruption in Romania. High barriers to new party entry help protect the PSD, the PNL, and the PDL from a new "clean hands party' like the GERB (SAR 2011). However, should the PSD control the next government, corruption will deepen and the balance of power will shift (further) against actors working for domestic institutional change.

\section{Conclusions}

Four years after joining the EU, Bulgaria and Romania still lag significantly behind the EU ECE 8 in stamping down on corruption and improving the quality of the judiciary. It is unclear whether episodic bursts of domestic institutional change can overcome deeply entrenched corruption in state institutions sufficiently to close this gap. At the same time, the two countries are performing substantially better than the EU-eligible states from the Western Balkans, with the exception of Croatia (see also Noutcheva and Düzgit 2012). Croatia outperforms Bulgaria and Romania on the rule of law and control of corruption indicators (Figures 3 and 4) - but only slightly. This is interesting in light of statements by the Commission in 2011 that it has no intention of including a CVM mechanism in any future accession treaty (Eur Activ, 4 January 2011). The Commission may be planning for the remaining candidates in the Western Balkans to get all reforms done before they join. Should they fall short, however, we show that the CVM can help mobilise institutional change. Our case studies show that both governments have responded to specific demands in the CVM reports, suggesting strongly that without the CVM there would be less reform.

We argue that the interplay of EU and domestic incentives explains Bulgaria's reinvigorated efforts and Romania's more mixed record in corruption control and judicial reform. In Bulgaria the EU exercised its leverage decisively in 2008 by freezing some EU funds and pursuing in-depth investigations of corruption. A new party, the GERB, used a very strong anti-corruption platform to establish itself in the party system and win the 2009 parliamentary elections. Working in tandem with vocal domestic groups, the EU's CVM mechanism and the freezing of EU funds helped highlight the problem of corruption for the electorate, making this platform even more attractive - and difficult to abandon.

In contrast, in Romania since accession there has been no decisive use of EU leverage that has helped galvanise the voters. Domestic momentum, which seemed strong from 2005 to 2007, has diminished as major political parties have openly opposed reform. The PDL party that controls the coalition government and includes President Basescu has the strongest corruption-fighting agenda of the three main Romanian parties. As EU pressure intensified significantly on Romania in 2010, the PDL battled opposition parties in order to renew some reforms while also vehemently 
criticising the CVM. But the PDL has lost ground in the polls to parties that have flagrantly thwarted attempts to fight corruption, signalling that corruption may be a lower priority than for voters in Bulgaria. The decision by EU members in late 2010 to use Schengen entry as a reward for meeting CVM benchmarks has nevertheless triggered some reform in Romania, as in Bulgaria, since Schengen membership is popular with citizens. This fits our broader argument that EU incentives for reform are important - but sustained domestic incentives centred on winning elections and holding power are crucial to ongoing reforms that consolidate the rule of law, which explains the mixed reform record of Romania.

\section{Acknowledgements}

We would like to thank two anonymous referees, Tanja A. Börzel, Tim Haughton and Thomas Risse for their very helpful comments. We also thank Inés Valdez for research assistance, and several officials of the European Commission and the Council for their insights. Our research was supported by a grant from the European Commission to the European Union Center of Excellence at UNC - Chapel Hill.

\section{Notes}

1. The reports are available at http://ec.europa.eu/dgs/secretariat_general/cvm/progress_ reports_en.htm

2. On Daniel Morar and his star reputation in Brussels, see 'Beacon of Hope,' Europeanvoice. com, 11 December 2008.

3. The Diplomat Online, Bucharest, October 2010, available at http://www.thediplomat.ro/ articol.php?id $=1440$

4. Available at http://blogs.ft.com/brusselsblog/2010/12/france-and-germany-vs-bulgaria-andromania/

\section{References}

Börzel, Tanja A., and Yasemin Pamuk (2012). 'Pathologies of Europeanization. Fighting Corruption in the Southern Caucasus', West European Politics, 35:1, 79-97.

Börzel, Tanja A., and Thomas Risse (2012). 'From Europeanisation to Diffusion: Introduction', West European Politics, 35:1, 1-19.

Buniewicz, Natalia, et al. (2009). 'Funding the Fight against Corruption in Romania and Bulgaria', Johns Hopkins University School of Advanced International Studies (SAIS) Working Paper.

Cameron, David (2007). 'Post-Communist Democracy: The Impact of the European Union', Post-Soviet Affairs, 23:3, 185-217.

Center for the Study of Democracy (CSD) (2007). 'Anti-corruption Reforms in Bulgaria. Key Results and Risks', available at http://www.csd.bg/artShow.php?id=8558 (accessed 10 September 2010).

Center for the Study of Democracy (CSD) (2009). 'Crime without Punishment. Countering Corruption and Organized Crime in Bulgaria', available at http://www.csd.bg/artShow. php?id=9583 (accessed 10 September 2010). 
Center for the Study of Democracy (CSD) (2010). 'The Cooperation and Verification Mechanism Three Years Later: What Has Been Done and What Is Yet to Come', available at http://www.csd.bg/artShow.php?id=15187 (accessed 10 November 2011).

Cholova, Blagovesta (2010). 'Populism in Bulgaria: A Recent Phenomenon?' Paper presented at the 9th Belgian-Dutch Political Science Conference, 27-28 May, Leuven, Belgium.

Council of the European Union (2010). 'The Mechanism of Cooperation and Verification for Bulgaria and Romania - Adoption of Council Conclusions', COVEME 7, 13105/10.

Dimitrova, Antoaneta (2010). 'The New Member States of the EU in the Aftermath of Enlargement: Do New European Rules Remain Empty Shells?', Journal of European Public Policy, 17:1, 137-48.

Dix, Holger (2010). 'The Current Status of the Romanian National Integrity Agency', Report of the South East Europe Program, Konrad Adenauer Stiftung, available at http:// www.kas.de/rspsoe/en/publications/20138/

Epstein, Rachel (2008). In Pursuit of Liberalism: The Power and Limits of International Institutions in Postcommunist Europe. Baltimore, MD: The Johns Hopkins Press.

European Commission (2006). 'Commission Decision of 13/XII/2006', C (2006) 6570 final.

European Commission (2007). 'Report from the Commission to the European Parliament and the Council on Progress in Bulgaria under the Cooperation and Verification Mechanism', $\operatorname{COM}(2007) 377$ final, 27 June.

European Commission (2008). 'Report from the Commission to the European Parliament and the Council on Progress in Romania/Bulgaria under the Cooperation and Verification Mechanism', COM(2008) 494/495 final, 23 July.

European Commission (2009). 'Report from the Commission to the European Parliament and the Council on Progress in Bulgaria under the Cooperation and Verification Mechanism', $\operatorname{COM}(2009) 402$ final, 22 July.

European Commission (2010a). 'Report from the Commission to the European Parliament and the Council on Progress in Bulgaria/Romania under the Cooperation and Verification Mechanism', COM(2010) 400/401 final, 20 July.

European Commission (2010b). 'Standard Eurobarometer', EB 73, Spring.

European Commission (2011). 'Interim Report from the Commission to the European Parliament and the Council on Progress in Romania/Bulgaria under the Cooperation and Verification Mechanism', COM(2011) 80/81 final, 18 February.

Freedom House (2010). Nations in Transit. Washington, DC: Freedom House, Inc.

Ganev, Venelin (2007). Preying on the State: The Transformation of Bulgaria after 1989. Ithaca, NY: Cornell University Press.

Geissler, Thorsten, and Corina Rebegea (2011). 'The Old and New Romanian Superior Council of Magistracy', Konrad-Adenauer Stiftung, available at http://www.kas.de/rspsoe/en/ publications $/ 22512 /$

Grabbe, Heather (2006). The EU's Transformative Power: Europeanization through Conditionality in Central and Eastern Europe. London: Palgrave.

Haughton, Tim (2007). 'Half Full But Also Half Empty: Conditionality, Compliance and the Quality of Democracy in Central and Eastern Europe', Political Studies Review, 5:2, 233-46.

Kaufmann, Daniel, Aart Kraay, and Massimo Mastruzzi (2009). 'Governance Matters VIII: Aggregate and Individual Governance Indicators, 1996-2008', World Bank Policy Research Working Paper No. 4978, available at http://ssrn.com/abstract=1424591

Keohane, Robert O. (1984). After Hegemony. Cooperation and Discord in the World Political Economy. Princeton, NJ: Princeton University Press.

Levitz, Philip, and Grigore Pop-Eleches (2009). 'Why No Backsliding? The EU's Impact on Democracy and Governance Before and After Accession', Comparative Political Studies, 43:4, 457-85.

Levitz, Philip, and Grigore Pop-Eleches (2010). 'Monitoring, Money and Migrants: Countering Post-Accession Backsliding in Bulgaria and Romania', Europe-Asia Studies, 62:3, 461-79.

Noutcheva, Gergana, and Dimitar Bechev (2008). 'The Successful Laggards: Bulgaria and Romania's Accession to the EU', East European Politics and Societies, 22:1, 114-44. 
Noutcheva, Gergana, and Senem Aydin Düzgit (2012). 'Lost in Europeanisation? The Western Balkans and Turkey', West European Politics, 35:1, 59-78.

Pop-Eleches, Grigore (2008). 'A Party for All Seasons: Electoral Adaptation of Romanian Communist Successor Parties', Communist and Post-Communist Studies, 41:4, 465-79.

Primatarova, Antoinette (2010). 'On High Stakes, Stakeholders and Bulgaria's EU Membership', unpublished paper, Center for European Policy Studies, Brussels.

Ristei, Mihaiela (2010). 'The Politics of Corruption: Political Will and the Rule of Law in PostCommunist Romania', Journal of Communist Studies and Transition Politics, 26:3, 341-62.

SAR (Romanian Academic Society) (2011). 'Beyond Perception: Has Romania's Governance Improved after 2004?', available at http://www.sar.org.ro

Schimmelfennig, Frank, and Ulrich Sedelmeier (2004). 'Governance by Conditionality: EU Rule Transfer to the Candidate Countries of Central and Eastern Europe', Journal of European Public Policy, 11:4, 661-79.

Sedelmeier, Ulrich (2008). 'After Conditionality: Post-accession Compliance with EU Law in East Central Europe', Journal of European Public Policy, 15:6, 806-25.

Sedelmeier, Ulrich (2011). 'Europeanisation in New Member and Candidate States', Living Reviews in European Governance, 6:1, available at http://europeangovernance.livingreviews. org/Articles/lreg-2011-1/

Sedelmeier, Ulrich (2012). 'Is Europeanisation through Conditionality Sustainable? Lock-in of Institutional Change after EU Accession', West European Politics, 35:1, 20-38.

Spendzharova, Aneta (2008). 'For the Market or "For Our Friends"? The Politics of Banking Sector Legal Reform in the Post-Communist Region after 1989', Comparative European Politics, 6:4, 432-62.

Trauner, Florian (2009). 'Post-accession Compliance with EU Law in Bulgaria and Romania: A Comparative Perspective', European Integration online Papers, 13:2, Art. 21.

Treisman, Daniel (2007). 'What Have We Learned about the Causes of Corruption from Ten Years of Cross-National Empirical Research?', Annual Review of Political Science, 211-44.

Vachudova, Milada Anna (2005). Europe Undivided: Democracy, Leverage and Integration after Communism. Oxford: Oxford University Press.

Vachudova, Milada Anna (2008). 'Tempered by the EU? Political Parties and Party Systems Before and After Accession', Journal of European Public Policy, 15:6, 861-79.

Vachudova, Milada Anna (2009). 'Corruption and Compliance in the EU's Post-Communist Members and Candidates', Journal of Common Market Studies, 47:1, 43-62. 